\title{
Qualitative profiling of mono- and sesquiterpenols in aglycon libraries from Vitis vinifera L. Gewürztraminer using multidimensional gas chromatography-mass spectrometry
}

\author{
Philipp P. Könen ${ }^{1} \mathbb{D} \cdot$ Ines Stötzel ${ }^{1} \cdot$ Wilfried Schwab $^{2}$ (D) Matthias Wüst $^{1}$ (D)
}

Received: 9 November 2020 / Revised: 7 January 2021 / Accepted: 9 January 2021 / Published online: 10 February 2021

(c) The Author(s) 2021

\begin{abstract}
In grape berries (Vitis vinifera L.), sesquiterpenes are mainly accumulated as hydrocarbons in the epicuticular wax layer of grapes, whereas monoterpenes, which are predominantly present as alcohols, are glycosylated and are stored as glycosides in the vacuoles of grape berry cells. In this study, extensive analysis of grape berry hydrolysates by means of comprehensive two-dimensional gas chromatography-time-of-flight-mass spectrometry demonstrated that glycosylated sesquiterpene alcohols show very little structural diversity when compared to the sesquiterpene hydrocarbon fraction in the cuticle and are glycosylated to a rather low extent when compared to monoterpenols. Twenty-four enzymatically released terpenols were found in hydrolysates of the aromatic white wine variety Gewürztraminer (V. vinifera subsp. vinifera) after previous solidphase extraction and headspace solid-phase microextraction. The detection of only three sesquiterpene alcohols, namely farnesol, nerolidol and drimenol, shows that most sesquiterpene hydrocarbons do not have a related hydroxylated structure in grapes. Nevertheless, the presence of the acyclic aglycone farnesol and nerolidol may be of importance for the wine aroma, since these structural isomers can be converted into numerous sesquiterpenes by nonenzymatic acid-catalyzed reactions during wine production. Grape-derived glycosidically bound sesquiterpene alcohols, therefore, represent, in addition to free sesquiterpene hydrocarbons, another pool of compounds that may influence the aroma profile of wines.
\end{abstract}

Keywords Terpenes · Glycosides · Aglycones $\cdot$ Sesquiterpene alcohols $\cdot$ GC $\times$ GC $\cdot$ Wine aroma

\section{Introduction}

Terpenes play a key role as plant secondary metabolites for the aroma of grapes (Vitis vinifera $\mathrm{L}$.) and wines [1]. Both mono- $\left(\mathrm{C}_{10}\right)$ and sesquiterpenes $\left(\mathrm{C}_{15}\right)$, which are formed

Matthias Wüst

matthias.wuest@uni-bonn.de

Philipp P. Könen

koenen@uni-bonn.de

Ines Stötzel

ines.stoetzel@uni-bonn.de

Wilfried Schwab

wilfried.schwab@tum.de

1 Chair of Food Chemistry, Institute of Nutritional and Food Sciences, University of Bonn, Endenicher Allee 19C, 53115 Bonn, Germany

2 Biotechnology of Natural Products, TUM School of Life Sciences, Technical University of Munich, Liesel-Beckmann-Str. 1, 85354 Freising, Germany via the cytosolic mevalonate-dependent metabolic pathway (MVA) and the mevalonate-independent 1-deoxy-D-xylulose 5-phosphate/2-C-methyl-D-erythritol 4-phosphate biosynthesis pathway (DOXP/MEP) occurring in plastids [2, 3], are of central importance for the aroma $[4,5]$. According to current knowledge, monoterpenes are stored predominantly as sugar bound alcohols in the vacuole whereas sesquiterpenes are accumulated as hydrocarbons in the nonpolar epicuticular wax layer of grape berries [6]. While free and volatile terpenes contribute directly to the aroma, a much larger fraction of glycosidically bound, non-volatile and thus aroma-inactive terpenoids is referred to as "hidden aromatic potential" in ripe grapes [7-9]. In 1974, the first evidence of glycosidically bound terpenes in grape berries was published by Cordonnier and Bayonove [10]. In the following decade, Williams et al. confirmed the presence of monoterpene glycosides by hydrolytic cleavage of the glycosidic bond, identifying both acyclic monoterpene alcohols such as linalool, nerol and geraniol as well as monocyclic terpenols such as $\alpha$-terpineol as released aglycones 
[11-13] . 6- $O-\alpha-\mathrm{L}-\mathrm{Rhamnopyranosyl-} \beta$-D-glucopyranosides, 6 - $O$ - $\alpha$-L-arabinofuranosyl- $\beta$-D-glucopyranosides, $6-O-\beta$-D-apiofuranosyl- $\beta$-D-glucopyranosides and $\beta$-Dglucopyranosides could be determined as sugar residues of monoterpene glycosides [11, 14]. While monoterpene glycosides in grapes have been extensively investigated in recent years [15-18], glycosidically bound sesquiterpenes in $V$. vinifera are still largely unknown. The first sesquiterpene glycosides in grapes were recently tentatively identified using ultra-high-performance liquid chromatography (UHPLC) quadrupole time-of-flight (qTOF) mass spectrometry (MS), but without further characterization of the aglycones [19]. Since glycosidically bound terpene alcohols are partly released both enzymatically and acid catalytically during winemaking [20, 21], grape-derived sesquiterpene glycosides represent an unexplored aroma potential, in addition to monoterpene glycosides. The potential importance of sesquiterpene alcohols for the wine aroma has recently been demonstrated by microvinification experiments. The yeast-derived, acyclic sesquiterpene alcohols nerolidol and farnesol can be converted into numerous other sesquiterpenes by acid-catalyzed reactions during the vinification process, thus significantly altering the sesquiterpene profile of wines [22]. In the presented study, the terpene alcohols released from grape-derived terpene glycosides were analyzed using the Gewürztraminer variety. The glycosidically bound terpenes from isolated exocarp of grapes were separated and concentrated using solid-phase extraction (SPE) and subsequently hydrolyzed enzymatically. The hydrolysates were analyzed by comprehensive two-dimensional gas chromatography-time-of-flight-mass spectrometry (GC $\times$ GC-TOF-MS) after previous headspace solid-phase microextraction (HS-SPME).

\section{Materials and methods}

\section{Chemicals}

Milli-Q water, ethanol (purity: $\geq 99.8 \%$ ) and zinc sulfate (purity: 99.9\%) were purchased from VWR International (Darmstadt, HE, Germany). The solvents dichloromethane (purity: 99.99\%) and methanol (purity: $\geq 99.9 \%$ ) were acquired from Fisher Scientific UK Limited (Loughborough, Leicestershire, UK) and Honeywell (Seelze, NI, Germany). Di-sodium hydrogen phosphate (purity: $\geq 99 \%$ ) and sodium dihydrogen phosphate monohydrate (purity: $\geq 99 \%$ ) were obtained from Sigma-Aldrich Chemie $\mathrm{GmbH}$ (Taufkirchen, BY, Germany). Potassium ferrocyanide trihydrate (purity: $\geq 99 \%$ ) was acquired from Acros Organics (Geel, Antwerp Province, Belgium). Citric acid monohydrate (purity: $\geq 99.5 \%$ ) and geraniol (purity: $\geq 90 \%$ ) were purchased from Carl Roth GmbH \& Co. KG (Karlsruhe,
BW, Germany) and the enzyme preparation ( $\beta$-glucosidase, polygalacturonase) from Oenobrands SAS (Montpellier, Occitanie, France). The compounds citronellol (purity: $\geq 95 \%$ ), nerol (purity: 98.7\%), carvacrol (purity: 99.4\%), thymol (purity: $>99.9 \%$ ), menthol (purity: 99.3\%), dihydrocitronellol (purity: $98.3 \%$ ) and a $\mathrm{C}_{7}-\mathrm{C}_{30}$ saturated alkane standard solution (certified reference material) were obtained from Sigma-Aldrich (Steinheim, BW, Germany). Nerolidol (cis + trans, purity: $97.5 \%$ ), farnesol (mixture of isomers, purity: $98.0 \%$ ), $\alpha$-terpineol (purity: $96 \%$ ) and linalool (purity: 98.5\%) were purchased from Alfa Aesar (Ward Hill, MA, USA).

\section{Sample material}

The grape berries were sampled on two dates, September 15, 2016 and October 4, 2016 from two aromatic clones (11 Gm and FR 46-106) of Gewürztraminer at the Hochschule Geisenheim University (Geisenheim, HE, Germany; GPS coordinates: 49.98505, 7.94582; altitude: $96 \mathrm{~m}$ a.s.1). The stage of maturation of the grapes was described on the basis of refractometrically determined soluble solids (September 15, 2016: $11 \mathrm{Gm}, 19.0^{\circ} \mathrm{Bx}$; FR 46-106, $19.5^{\circ} \mathrm{Bx}$ and October 4, 2016: $11 \mathrm{Gm}, 21.0^{\circ} \mathrm{Bx}$; FR 46-106, 23.0ำ.

\section{Sample preparation}

\section{Tissue extraction}

The isolation of the terpene glycosides from the skin of grape berries was carried out based on a previous paper [23]. As described, the skin of the grapes was peeled off and adherent pulp was removed. For the terpene analysis, $20 \mathrm{~g}$ (fresh weight) of the grape berry skin was grounded in liquid nitrogen. The material was extracted under nitrogen and exclusion of light in a phosphate buffer $(0.1 \mathrm{M}$; $\left.\mathrm{Na}_{2} \mathrm{HPO}_{4} / \mathrm{NaH}_{2} \mathrm{PO}_{4} ; \mathrm{pH} 7\right)$ and $13 \%$ (v/v) ethanol for $24 \mathrm{~h}$. The extracts were clarified with Carrez reagents and then centrifuged at $24,000 \times g, 5{ }^{\circ} \mathrm{C}$ for $20 \mathrm{~min}$. The supernatant was purified and concentrated by solid-phase extraction.

\section{Solid-phase extraction (SPE)}

To separate the free terpenes from the glycosidically bound terpenes a $500 \mathrm{mg}$ Lichrolut EN column from Merck KGaA (Darmstadt, HE, Germany) was conditioned as stated previously [24]. The free terpenes were eluted with dichloromethane and the glycosidically bound terpenes with methanol. The fraction containing the separated glycosidically bound terpenes was concentrated under reduced pressure until dryness. 


\section{Hydrolysis}

The residue was dissolved in $20 \mathrm{~mL}$ citrate-HCl-buffer $(0.1 \mathrm{M} ; \mathrm{pH} 4)$ and $100 \mathrm{mg}$ of the enzyme preparation was added. All samples were stored at $-80{ }^{\circ} \mathrm{C}$ until analysis. Sample preparation was performed three times, resulting in three biological replicates.

\section{Analysis of the hydrolysates}

The hydrolysates of the grape berries were thawed and homogenized before analysis. A Combi PAL-xt autosampler with a heatable agitator and fiber conditioning station from CTC Analytics (Zwingen, BL, Switzerland) was used. The terpene alcohols were extracted from headspace using a mixed SPME fiber for volatile and semivolatile compounds $\left(\mathrm{C}_{3}-\mathrm{C}_{20}\right)$ from Supelco (Bellefonte, PA, USA), based on a method described by Welke et al. [25]. After each analysis, the SPME fiber was baked-out to avoid sample carryover. In addition, empty vials were measured as control. The injection was carried out into a $7890 \mathrm{~B}$ gas chromatograph from Agilent Technologies (Bellefonte, PA, USA) equipped with a ZX2 GC $\times$ GC cryogenic modulator from Zoex Corp (Houston, TX, USA). Gas chromatographic separation was performed by combining a highly polar capillary column from Agilent Technologies (Bellefonte, PA, USA) with a medium polar GC column from MEGA s.n.c. (Legnano, MI, Italy), a combination that was used in a previous work for the analysis of sesquiterpene hydrocarbons in grape berry exocarp [26]. The GC $\times$ GC separation was followed by a mass spectrometric analysis using a BenchTOF-Select time-of-flight-mass spectrometer from Markes International Limited (Llantrisant, Wales, UK). The method parameters are listed in Table 1. Available mono- and sesquiterpene standards were diluted in ethanol and the resulting $1 \mathrm{mg} / \mathrm{kg}$ solutions were injected with a liquid syringe ( $1 \mu \mathrm{L}$ injection volume, split mode).
Table 1 HS-SPME-GC $\times$ GCTOF-MS conditions used for the analysis of hydrolysates from grape berries (Gewürztraminer cultivar)

\begin{tabular}{|c|c|}
\hline & Conditions \\
\hline \multicolumn{2}{|l|}{ HS-SPME } \\
\hline HS vial & $10 \mathrm{~mL}$ headspace vial (screw cap) \\
\hline Sample volume & $1 \mathrm{~mL}$ hydrolysate \\
\hline SPME fiber & DVB/CAR/PDMS ${ }^{\mathrm{a}} ; 50 / 30 \mu \mathrm{m} ; 2 \mathrm{~cm}$; Stableflex; $24 \mathrm{Ga}$ \\
\hline Incubation conditions & $45^{\circ} \mathrm{C} / 0 \mathrm{rpm} / 10 \mathrm{~min}$ \\
\hline Extraction conditions & $45^{\circ} \mathrm{C} / 0 \mathrm{rpm} / 30 \mathrm{~min}$ \\
\hline Desorption conditions & $250^{\circ} \mathrm{C} / 5 \mathrm{~min}$ \\
\hline Fiber bake-out conditions & $250{ }^{\circ} \mathrm{C} / 15 \mathrm{~min}$ \\
\hline \multicolumn{2}{|l|}{$\mathrm{GC} \times \mathrm{GC}$} \\
\hline Injector mode & Splitless \\
\hline Injector temperature & $250^{\circ} \mathrm{C}$ \\
\hline 1D GC column & DB-WAX Ultra Inert $\left(30 \mathrm{~m} \times 0.25 \mathrm{~mm} \times 0.25 \mu \mathrm{m}^{\mathrm{b}}\right)$ \\
\hline 2D GC column & MEGA-17 MS FAST $\left(1.7 \mathrm{~m} \times 0.10 \mathrm{~mm} \times 0.10 \mu \mathrm{m}^{\mathrm{b}}\right)$ \\
\hline Carrier gas & Helium \\
\hline Gas flow & Constant flow, $1.0 \mathrm{~mL} \mathrm{~min}-1$ \\
\hline Initial inlet pressure & $24 \mathrm{psi}$ \\
\hline GC oven program & $\begin{array}{l}35^{\circ} \mathrm{C}(5 \mathrm{~min}) / 5^{\circ} \mathrm{C}_{\min ^{-1} \text { to } 120{ }^{\circ} \mathrm{C}} \\
(0 \mathrm{~min}) / 3^{\circ} \mathrm{C} \min ^{-1} \text { to } 220^{\circ} \mathrm{C}(5 \mathrm{~min})\end{array}$ \\
\hline Modulator temperature offset & $+25^{\circ} \mathrm{C}$ \\
\hline Modulation period & $5 \mathrm{~s}$ \\
\hline Pulse length & $350 \mathrm{~ms}$ \\
\hline \multicolumn{2}{|l|}{ TOF-MS } \\
\hline MS transfer line temperature & $250^{\circ} \mathrm{C}$ \\
\hline Ion source temperature & $250^{\circ} \mathrm{C}$ \\
\hline Ionization mode & Electron impact (EI), $-70 \mathrm{eV}$ \\
\hline Detector voltage & $-2214 \mathrm{~V}$ \\
\hline Mass range & $35-250 \mathrm{~m} / \mathrm{z}$ \\
\hline Scan rate & $100 \mathrm{~Hz}$ \\
\hline
\end{tabular}

${ }^{a}$ Divinylbenzene (DVB)/carboxen (CAR)/polydimethylsiloxane (PDMS)

${ }^{\mathrm{b}}$ Length $\times$ internal diameter $\times$ film thickness 


\section{Data analysis}

Data were collected in ProtoTof (version 2.0) as *. LSC files and processed using the software platform ChromSpace (version 1.5.1). Both programs are from Markes International Limited (Llantrisant, Wales, UK). The data files were subjected to a dynamic background compensation $(\mathrm{dbc})$ with a peak width of $100 \mathrm{~ms}$. Data analysis was carried out using filtering methods (extracted-ion chromatogram, parametric filtering settings) and integration algorithms (persistence, deconvolution). Compound identification was performed using mass spectra (MS), retention indices (RI) and authentic standards (STD). Recorded mass spectra were compared with library spectra from the National Institute of Standards and Technology (NIST) database of the mass spectral search program (NIST, Gaithersburg, MD, USA; version 2.2). The similarity of the mass spectra was indicated by match factors (MF) and reverse match factors (RMF). After liquid injection of a saturated $n$-alkane standard solution $\left(\mathrm{C}_{7}-\mathrm{C}_{30}\right)$, the retention indices $\left(\mathrm{RI}_{\mathrm{exp}}\right)$ were calculated using the method of van Den Dool and Kratz for temperature-programmed gas chromatography [27]. The mono- and sesquiterpene alcohols were subsequently identified by comparing the experimentally determined retention indices with literature values $\left(\mathrm{RI}_{\mathrm{lit}}\right)$. The sesquiterpene alcohols $(E)$ nerolidol and farnesol as well as the monoterpene alcohols linalool, menthol, dihydrocitronellol, $\alpha$-terpineol, $\beta$-citronellol, nerol, geraniol, thymol and carvacrol were additionally identified by commercially available standard compounds. To determine the ratio of sesquiterpene aglycones to monoterpene aglycones, the mean values of the peak areas of all terpenols were summed and the percentage of each analyte calculated.

\section{Results and discussion}

The gas chromatographic separation of terpene aglycones from grapes ( $V$. vinifera $L$.) requires prior cleavage of the glycosidic bond by means of enzymes or acids. By combining suitable extraction methods (SPE-HS-SPME) with comprehensive two-dimensional gas chromatography-timeof-flight-mass spectrometry (GC $\times$ GC-TOF-MS), a total of 24 terpene aglycones were found in hydrolysates of grape berry exocarp. Figure 1 shows the two-dimensional separation of the released terpene alcohols.

Twenty-one monoterpene alcohols were identified in the hydrolysates of grape berries of the terpene-rich white wine variety Gewürztraminer ( $V$. vinifera subsp. vinifera, clones $11 \mathrm{Gm}$ and FR 46-106). Among these, the structural diversity of the $p$-menthane-related monoterpenols is remarkable. The detection of menthol is particularly interesting because its precursor piperitone contributes to the positive mint aroma of red Bordeaux wines, as described by Picard et al. [28]. The large number of monoterpenols found in the hydrolysates is in marked contrast to the few free monoterpene alcohols found in the volatile profile of ripe grape berries (Gewürztraminer cultivar) identified by May [29]. The GC $\times$ GC-TOF-MS measurements thus confirm the assumption that monoterpenols are predominantly glycosidically bound in grapes [6].

Although more than $80 \%$ of the peak area of all terpene aglycones detected can be attributed to only six monoterpenols, nerol, $\alpha$-terpineol, linalool, geraniol, $\beta$-citronellol and dihydrocarveol, the first detection of grape-derived sesquiterpene aglycones in the Gewürztraminer variety, especially $(E)$-nerolidol and farnesol [30, 31], is noteworthy. While previous studies showed that free mono- and sesquiterpene hydrocarbons as well as monoterpene alcohols mainly characterize the wine aroma, the detection of grape-derived

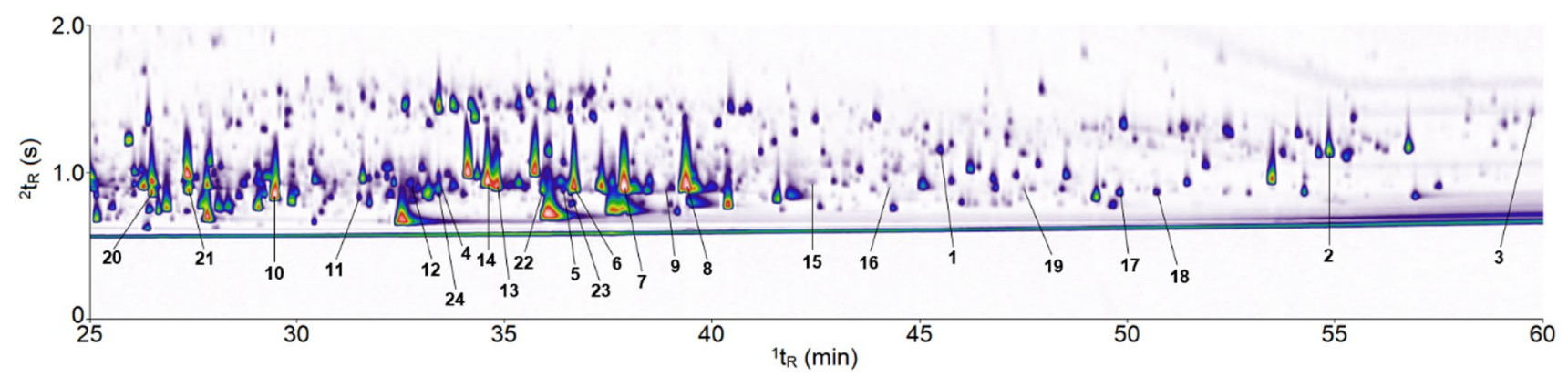

Fig. $1 \mathrm{GC} \times \mathrm{GC}-\mathrm{TOF}-\mathrm{MS}$ total ion chromatogram (TIC) of a hydrolysate from grape berries of the white wine variety Gewürztraminer (Vitis vinifera subsp. vinifera). The $x$ axis represents the primary column retention time $\left({ }^{1} t_{\mathrm{R}}\right)$ and the $y$ axis corresponds to the retention time on the secondary column $\left({ }^{2} t_{\mathrm{R}}\right)$. The peak intensity, which is proportional to analyte concentration, is represented by color-coding from low (violet) to high (red) on a white background. Note that a logarithmic color gradient has been selected, as numerous trace volatile compounds would otherwise not be visible in a single contour plot due to some very dominant peaks. Peak numbers of mono- and sesquiterpene aglycones released by enzymatic hydrolysis refer to those of Fig. 2 and Table 2 
Fig. 2 Structural formulas of the enzymatically released terpene alcohols from grapederived terpene glycosides, grouped by sesquiterpene and monoterpene aglycones. 1-2 acyclic sesquiterpene alcohols, 3 bicyclic sesquiterpene alcohol, 4-11 acyclic monoterpene alcohols, 12-23 monocyclic monoterpene alcohols, 24 bicyclic monoterpene alcohol

Sesquiterpene aglycones<smiles>C=CC(C)(O)CCC=C(C)CCC=C(C)C</smiles>

(1)

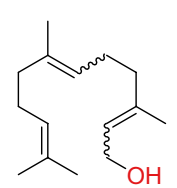

(2)<smiles>CC1=CCC2C(CO)C(C)(C)CCCC12C</smiles>

(3)

Monoterpene aglycones

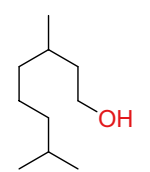

(4)<smiles>C=CC(=C)CCC(C)(O)C=C</smiles>

(11)

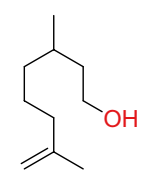

(5)

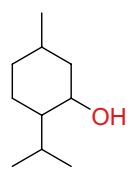

(12)<smiles>CC(C)=CCCC(C)CCO</smiles>

(6)<smiles>C=C(C)C1CCC(C)C(O)C1</smiles>

(13)

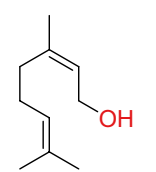

(7)

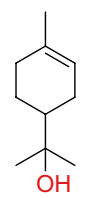

(14)<smiles>CC(C)=CCCC(C)=CCO</smiles>

(8)

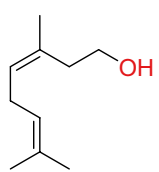

(9)<smiles>C=C(C)C1CC=C(CO)CC1</smiles>

(16)

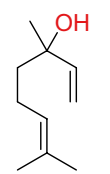

(10)<smiles>Cc1ccc(C(C)C)c(O)c1</smiles>

(17)

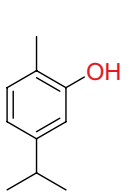

(18)<smiles>CC(C)c1ccc(CO)cc1</smiles>

(19)

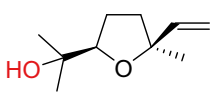

(20)

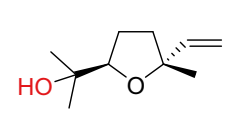

(21)<smiles>C=C[C@]1(C)CCC(O)C(C)(C)O1</smiles>

(22)<smiles>C=C[C@]1(C)CCC(O)C(C)(C)O1</smiles>

(23)<smiles>C=C1C2CC3CC2C13O</smiles>

(24) sesquiterpene aglycones reveals an undiscovered pool of potential aroma components in the Gewürztraminer variety.

It is known that wine yeasts are able to form the sesquiterpene alcohols farnesol and nerolidol [32]. Recently, deuterium-labeling experiments showed that yeast-derived farnesol and nerolidol significantly alter the terpene profile of wines during the fermentation process [22]. The sesquiterpene alcohols act as precursors for the formation of numerous other sesquiterpenes. Due to the slightly acidic $\mathrm{pH}$ during vinification, many sesquiterpenes can already be formed by acid catalysis from nerolidol and farnesol without the presence of corresponding sesquiterpene cyclases [33].

In addition to the acyclic sesquiterpene alcohols nerolidol and farnesol, the first tentative and indirect detection of glycosidically bound drimenol in grape berry exocarp was obtained by $\mathrm{GC} \times \mathrm{GC}-\mathrm{TOF}-\mathrm{MS}$ analysis. The bicyclic drimenol has a drimane skeleton that has not been found in $V$. vinifera $\mathrm{L}$. so far. The detection of drimenol is particularly interesting due to the antifungal activity against Botrytis cinerea [34], a pathogen that affects numerous plants including grapes [35]. At this point, it should be mentioned that drimenol can also be formed by rearrangement from farnesol [36].

The fact that only three sesquiterpene alcohols were found in the hydrolysates after extensive $\mathrm{GC} \times \mathrm{GC}$ analysis shows that sesquiterpene alcohols are rather by-products of sesquiterpene hydrocarbon synthases that are responsible for the biosynthesis of structurally diverse carbon skeletons. Glycosylated sesquiterpene alcohols are probably stored in the vacuole of the grape berry cell as watersoluble flavor precursors, similar to glycosylated monoterpene alcohols [37].

It should also be noted that both, numerous monoterpene hydrocarbons and numerous monoterpene alcohols are present in grape berries. In the case of sesquiterpenes, hydrocarbons dominate the volatile profile without the corresponding sesquiterpene alcohol analogues. However, these grape-derived glycosidically bound sesquiterpene alcohols, in particular farnesol and nerolidol, represent another important source of aroma precursors that may influence the wine aroma. 
Table 2 Identified terpene aglycones enzymatically hydrolyzed from terpene glycosides in Gewürztraminer grapes (Vitis vinifera subsp. vinifera) using SPE-HS-SPME-GC $\times$ GC-TOF-MS

\begin{tabular}{|c|c|c|c|c|c|c|c|}
\hline \multirow[t]{2}{*}{ No. } & \multirow[t]{2}{*}{ Terpene aglycone } & \multirow[t]{2}{*}{ Molecular formula } & \multirow[t]{2}{*}{ Percentage $^{c}$} & \multicolumn{4}{|c|}{ Identification criteria } \\
\hline & & & & $\mathrm{RI}_{\exp }{ }^{\mathrm{d}}$ & $\mathrm{RI}_{\mathrm{lit}}{ }^{\mathrm{e}}$ & MS (MF, RMF) & STD $^{g}$ \\
\hline \multicolumn{8}{|c|}{ Sesquiterpene aglycones } \\
\hline 1 & $(E)-$ Nerolidol $^{\mathrm{a}}$ & $\mathrm{C}_{15} \mathrm{H}_{26} \mathrm{O}$ & $0.47 \pm 0.31 \%$ & 2040 & 2040 [38] & 805,852 & a. ${ }^{\mathrm{i}}$ \\
\hline 2 & Farnesol $^{\mathrm{a}}$ & $\mathrm{C}_{15} \mathrm{H}_{26} \mathrm{O}$ & $2.68 \pm 1.71 \%$ & 2357 & 2354 [39] & 832,835 & a. ${ }^{\mathrm{i}}$ \\
\hline 3 & Drimenol $^{\mathrm{b}}$ & $\mathrm{C}_{15} \mathrm{H}_{26} \mathrm{O}$ & $0.19 \pm 0.03 \%$ & $2505^{\mathrm{h}}$ & 2494 [40] & 800,816 & n.a. ${ }^{j}$ \\
\hline \multicolumn{8}{|c|}{ Monoterpene aglycones } \\
\hline 20 & (Z)-Furan linalool oxide ${ }^{b}$ & $\mathrm{C}_{10} \mathrm{H}_{18} \mathrm{O}_{2}$ & $3.05 \pm 0.72 \%$ & 1454 & $1454[41]$ & 842,850 & n.a. ${ }^{\mathrm{j}}$ \\
\hline 21 & (E)-Furan linalool oxide ${ }^{b}$ & $\mathrm{C}_{10} \mathrm{H}_{18} \mathrm{O}_{2}$ & $3.39 \pm 1.02 \%$ & 1483 & $1483[42]$ & 804,814 & n.a. ${ }^{\mathrm{j}}$ \\
\hline 10 & Linalool $^{\mathrm{a}}$ & $\mathrm{C}_{10} \mathrm{H}_{18} \mathrm{O}$ & $13.84 \pm 0.84 \%$ & 1547 & $1547[43]$ & 797,808 & a. ${ }^{\mathrm{i}}$ \\
\hline 11 & Hotrienol $^{\mathrm{b}}$ & $\mathrm{C}_{10} \mathrm{H}_{16} \mathrm{O}$ & $0.13 \pm 0.04 \%$ & 1608 & $1613[44]$ & 729,763 & n.a. ${ }^{\mathrm{j}}$ \\
\hline 12 & Menthol $^{\mathrm{a}}$ & $\mathrm{C}_{10} \mathrm{H}_{20} \mathrm{O}$ & $0.86 \pm 0.13 \%$ & 1645 & $1644[45]$ & 856,874 & a. ${ }^{\mathrm{i}}$ \\
\hline 24 & $(E)$-Pinocarveol ${ }^{\mathrm{b}}$ & $\mathrm{C}_{10} \mathrm{H}_{16} \mathrm{O}$ & $1.19 \pm 0.19 \%$ & 1666 & 1659 [46] & 815,831 & n.a. ${ }^{j}$ \\
\hline 4 & Dihydrocitronellol $^{\mathrm{a}}$ & $\mathrm{C}_{10} \mathrm{H}_{22} \mathrm{O}$ & $0.17 \pm 0.02 \%$ & 1669 & $1666[47]$ & 732,748 & a. \\
\hline 14 & $\alpha$-Terpineol $^{\mathrm{a}}$ & $\mathrm{C}_{10} \mathrm{H}_{18} \mathrm{O}$ & $15.70 \pm 1.58 \%$ & 1703 & $1703[48]$ & 848,889 & a. ${ }^{\mathrm{i}}$ \\
\hline 13 & Dihydrocarveol $^{\mathrm{b}}$ & $\mathrm{C}_{10} \mathrm{H}_{18} \mathrm{O}$ & $10.43 \pm 0.64 \%$ & 1709 & 1702 [49] & 724,757 & n.a. ${ }^{j}$ \\
\hline 22 & (Z)-Pyran linalool oxide ${ }^{b}$ & $\mathrm{C}_{10} \mathrm{H}_{18} \mathrm{O}_{2}$ & $2.05 \pm 0.45 \%$ & 1744 & $1744[50]$ & 774,801 & n.a. ${ }^{j}$ \\
\hline 5 & $\alpha$-Citronellol ${ }^{\mathrm{b}}$ & $\mathrm{C}_{10} \mathrm{H}_{20} \mathrm{O}$ & $0.25 \pm 0.03 \%$ & 1759 & $1767[47]$ & 883,924 & n.a. ${ }^{\mathrm{j}}$ \\
\hline 23 & (E)-Pyran linalool oxide ${ }^{b}$ & $\mathrm{C}_{10} \mathrm{H}_{18} \mathrm{O}_{2}$ & $0.52 \pm 0.51 \%$ & 1764 & $1763[51]$ & 828,839 & n.a. ${ }^{\mathrm{j}}$ \\
\hline 6 & $\beta$-Citronellol ${ }^{\mathrm{a}}$ & $\mathrm{C}_{10} \mathrm{H}_{20} \mathrm{O}$ & $11.33 \pm 2.02 \%$ & 1767 & $1767[52]$ & 846,859 & a. ${ }^{\mathrm{i}}$ \\
\hline 7 & Nerol $^{\mathrm{a}}$ & $\mathrm{C}_{10} \mathrm{H}_{18} \mathrm{O}$ & $20.45 \pm 3.91 \%$ & 1805 & $1803[53]$ & 813,821 & a. ${ }^{\mathrm{i}}$ \\
\hline 9 & $(Z)$-Iso-geraniol $^{\mathrm{b}}$ & $\mathrm{C}_{10} \mathrm{H}_{18} \mathrm{O}$ & $0.17 \pm 0.04 \%$ & 1835 & $1849[54]$ & 767,789 & n.a. ${ }^{\mathrm{j}}$ \\
\hline 8 & Geraniol $^{\mathrm{a}}$ & $\mathrm{C}_{10} \mathrm{H}_{18} \mathrm{O}$ & $11.50 \pm 0.44 \%$ & 1848 & $1848[55]$ & 804,809 & a. ${ }^{\mathrm{i}}$ \\
\hline 15 & $p$-Mentha-1-en-9-ol ${ }^{\mathrm{b}}$ & $\mathrm{C}_{10} \mathrm{H}_{18} \mathrm{O}$ & $0.17 \pm 0.03 \%$ & 1943 & 1948 [56] & 814,868 & n.a. ${ }^{j}$ \\
\hline 16 & Perillyl alcohol ${ }^{\mathrm{b}}$ & $\mathrm{C}_{10} \mathrm{H}_{16} \mathrm{O}$ & $0.03 \pm 0.01 \%$ & 2000 & 2004 [57] & 693,762 & n.a. ${ }^{\mathrm{j}}$ \\
\hline 19 & Cuminol $^{\mathrm{b}}$ & $\mathrm{C}_{10} \mathrm{H}_{14} \mathrm{O}$ & $0.08 \pm 0.01 \%$ & 2106 & $2101[58]$ & 763,804 & n.a. ${ }^{j}$ \\
\hline 17 & Thymol $^{\mathrm{a}}$ & $\mathrm{C}_{10} \mathrm{H}_{14} \mathrm{O}$ & $0.84 \pm 0.19 \%$ & 2182 & 2183 [59] & 876,898 & $\mathrm{a}^{\mathrm{i}}$ \\
\hline 18 & Carvacrol $^{\mathrm{a}}$ & $\mathrm{C}_{10} \mathrm{H}_{14} \mathrm{O}$ & $0.54 \pm 0.17 \%$ & 2213 & 2212 [60] & 905,916 & a. ${ }^{\mathrm{i}}$ \\
\hline
\end{tabular}

${ }^{a}$ Identified by retention index, mass spectrum and authentic standard

${ }^{\mathrm{b}}$ Tentatively identified by retention index and mass spectral data

${ }^{c}$ Percentage of aglycone determined by the sum of peak areas. The mean value and the standard deviation resulting from the integration of three biological replicates are given

${ }^{\mathrm{d}}$ Experimental retention indices on a polar DB-WAX Ultra Inert column calculated according to the method of van Den Dool and Kratz for temperature-programmed gas chromatography

${ }^{\text {e}}$ Retention indices reported in the literature for equivalent capillary GC columns

${ }^{\mathrm{f}}$ Mean mass spectral match quality. The mean values of the match factors (MF) and reverse match factors (RMF) for the respective terpene aglycones are listed

${ }^{\mathrm{g}}$ Liquid injection of an authentic standard for compound identification

${ }^{\mathrm{h}} \mathrm{RI}_{\exp }$ value has been extrapolated

${ }^{\mathrm{i}}$ An authentic standard was commercially available (a.) and was measured using GC $\times \mathrm{GC}-\mathrm{TOF}-\mathrm{MS}$. The purity of this reference material was documented in the "Materials and methods"

${ }^{\mathrm{j}}$ An authentic standard material was not available (n.a.) 
Acknowledgements We thank the DFG for financial support (WU 322/6-1 and INST 217/783-1 FUGG). The grapes of the white wine variety Gewürztraminer were harvested at the Hochschule Geisenheim University. We would like to thank the Department of Grapevine Breeding for providing the sample material.

Funding Open Access funding enabled and organized by Projekt DEAL. This work was supported by the German Research Foundation (DFG, WU 322/6-1 and INST 217/783-1 FUGG).

\section{Compliance with ethical standards}

Conflict of interest The authors declare that they have no conflict of interest.

Compliance with ethics requirements This article does not contain any studies with human or animal subjects.

Open Access This article is licensed under a Creative Commons Attribution 4.0 International License, which permits use, sharing, adaptation, distribution and reproduction in any medium or format, as long as you give appropriate credit to the original author(s) and the source, provide a link to the Creative Commons licence, and indicate if changes were made. The images or other third party material in this article are included in the article's Creative Commons licence, unless indicated otherwise in a credit line to the material. If material is not included in the article's Creative Commons licence and your intended use is not permitted by statutory regulation or exceeds the permitted use, you will need to obtain permission directly from the copyright holder. To view a copy of this licence, visit http://creativecommons.org/licenses/by/4.0/.

\section{References}

1. Mele MA, Kang H-M, Lee Y-T, Islam MZ (2020) Grape terpenoids: flavor importance, genetic regulation, and future potential. Crit Rev Food Sci Nutr 1-19

2. Luan F, Wüst M (2002) Differential incorporation of 1-deoxyD-xylulose into (3S)-linalool and geraniol in grape berry exocarp and mesocarp. Phytochemistry 60:451-459

3. May B, Lange BM, Wüst M (2013) Biosynthesis of sesquiterpenes in grape berry exocarp of Vitis vinifera $\mathrm{L}$.: evidence for a transport of farnesyl diphosphate precursors from plastids to the cytosol. Phytochemistry 95:135-144

4. Li Z, Howell K, Fang Z, Zhang P (2020) Sesquiterpenes in grapes and wines: occurrence, biosynthesis, functionality, and influence of winemaking processes. Compr Rev Food Sci Food Saf $19: 247-281$

5. Mateo JJ, Jiménez M (2000) Monoterpenes in grape juice and wines. J Chromatogr A 881:557-567

6. Schwab W, Wüst M (2015) Understanding the constitutive and induced biosynthesis of mono- and sesquiterpenes in grapes (Vitis vinifera): a key to unlocking the biochemical secrets of unique grape aroma profiles. J Agric Food Chem 63:10591-10603

7. Günata YZ, Bayonove CL, Baumes RL, Cordonnier RE (1985) The aroma of grapes I. Extraction and determination of free and glycosidically bound fractions of some grape aroma components. J Chromatogr A 331:83-90

8. Stahl-Biskup E, Intert F, Holthuijzen J, Stengele M, Schulz G (1993) Glycosidically bound volatiles-a review 1986-1991. Flavour Fragr J 8:61-80
9. Lamorte SA, Gambuti A, Genovese A, Selicato S, Moio L (2008) Free and glycoconjugated volatiles of $V$. vinifera grape 'Falanghina.' Vitis 47:241-243

10. Cordonnier R, Bayonove C (1974) Mise en évidence dans la baie de raisin, variété Muscat d'Alexandrie, de monoterpènes liés révélables par une ou plusieurs enzymes du fruit. CR Acad Sci Paris 278:3387-3390

11. Williams PJ, Strauss CR, Wilson B, Massy-Westropp RA (1982) Novel monoterpene disaccharide glycosides of Vitis vinifera grapes and wines. Phytochemistry 21:2013-2020

12. Williams PJ, Strauss CR, Wilson B, Massy-Westropp RA (1982) Studies on the hydrolysis of Vitis vinifera monoterpene precursor compounds and model monoterpene $\beta$-D-glucosides rationalizing the monoterpene composition of grapes. J Agric Food Chem 30:1219-1223

13. Williams PJ, Strauss CR, Wilson B, Massy-Westropp RA (1982) Use of $\mathrm{C}_{18}$ reversed-phase liquid chromatography for the isolation of monoterpene glycosides and nor-isoprenoid precursors from grape juice and wines. J Chromatogr A 235:471-480

14. Günata YZ, Dugelay I, Sapis J-C, Baumes R, Bayonove C (1994) Role of Enzymes in the Use of the Flavour Potential from Grape Glycosides in Winemaking. In: Schreier P, Winterhalter P (eds) Progress in flavour precursor studies. Proceedings of the international conference. Allured Publishing Corporation, Carol Stream, pp 219-245

15. Flamini R, De Rosso M, Panighel A, Dalla Vedova A, De Marchi F, Bavaresco L (2014) Profiling of grape monoterpene glycosides (aroma precursors) by ultra-high performance-liquid chromatography-high resolution mass spectrometry (UHPLC/QTOF). J Mass Spectrom 49:1214-1222

16. Stanitzek S (2014) Monoterpenylglucosyltransferasen aus Vitis vinifera: Funktionelle Charakterisierung und Analytik der Produkte mittels LC-MS/MS. Ph.D. thesis, University of Bonn

17. Hjelmeland AK, Ebeler SE (2015) Glycosidically bound volatile aroma compounds in grapes and wine: a review. Am J Enol Vitic 66:1-11

18. Wang X-j, Song H-c, Yang Y, Tao Y-s (2020) Chemical profile of terpene glycosides from Meili grape detected by GC-MS and UPLC-Q-TOF-MS. Eur Food Res Technol 246:2323-2333

19. Caffrey AJ, Lerno LA, Zweigenbaum J, Ebeler SE (2020) Direct analysis of glycosidic aroma precursors containing multiple aglycone classes in Vitis vinifera berries. J Agric Food Chem 68:3817-3833

20. Carrau FM, Boido E, Dellacassa E (2008) Terpenoids in grapes and wines: origin and micrometabolism during the vinification process. Nat Prod Commun 3:577-592

21. Sarry J-E, Günata YZ (2004) Plant and microbial glycoside hydrolases: volatile release from glycosidic aroma precursors. Food Chem 87:509-521

22. Könen PP, Wüst M (2020) Dissecting sesquiterpene profiles of Lemberger red wines using ex vivo tissue deuterium-labeling and comprehensive two-dimensional gas chromatography-timeof-flight-mass spectrometry. J Agric Food Chem 68:8936-8941

23. Bönisch F, Frotscher J, Stanitzek S, Rühl E, Wüst M, Bitz O, Schwab W (2014) A UDP-glucose: monoterpenol glucosyltransferase adds to the chemical diversity of the grapevine metabolome. Plant Physiol 165:561-581

24. Piñeiro Z, Palma M, Barroso CG (2004) Determination of terpenoids in wines by solid phase extraction and gas chromatography. Anal Chim Acta 513:209-214

25. Welke JE, Manfroi V, Zanus M, Lazarotto M, Alcaraz Zini C (2012) Characterization of the volatile profile of Brazilian Merlot wines through comprehensive two dimensional gas chromatography time-of-flight mass spectrometric detection. J Chromatogr A 1226:124-139 
26. Könen PP, Wüst M (2019) Analysis of sesquiterpene hydrocarbons in grape berry exocarp (Vitis vinifera L.) using in vivolabeling and comprehensive two-dimensional gas chromatography-mass spectrometry $(\mathrm{GC} \times \mathrm{GC}-\mathrm{MS})$. Beilstein J Org Chem 15:1945-1961

27. Van Den Dool H, Kratz PD (1963) A generalization of the retention index system including linear temperature programmed gas-liquid partition chromatography. J Chromatogr A 11:463-471

28. Picard M, Lytra G, Tempere S, Barbe J-C, De Revel G, Marchand S (2016) Identification of piperitone as an aroma compound contributing to the positive mint nuances perceived in aged Red Bordeaux wines. J Agric Food Chem 64:451-460

29. May B (2015) Biosynthese und Analytik von Sesquiterpenen in Weinbeeren (Vitis vinifera). Ph.D. thesis, University of Bonn

30. López R, Ezpeleta E, Sánchez I, Cacho J, Ferreira V (2004) Analysis of the aroma intensities of volatile compounds released from mild acid hydrolysates of odourless precursors extracted from Tempranillo and Grenache grapes using gas chromatographyolfactometry. Food Chem 88:95-103

31. Pedroza MA, Zalacain A, Lara JF, Rosario Salinas M (2010) Global grape aroma potential and its individual analysis by SBSEGC-MS. Food Res Int 43:1003-1008

32. Fagan GL, Kepner RE, Webb AD (1981) Production of linalool, cis- and trans-nerolidol, and trans, trans-farnesol by Saccharomyces fermentati growing as a film on simulated wine. Vitis 20:36-42

33. Gutsche CD, Maycock JR, Chang CT (1968) Acid-catalyzed cyclization of farnesol and nerolidol. Tetrahedron 24:859-876

34. Robles-Kelly C, Rubio J, Thomas M, Sedán C, Martinez R, Olea AF, Carrasco H, Taborga L, Silva-Moreno E (2017) Effect of drimenol and synthetic derivatives on growth and germination of Botrytis cinerea: evaluation of possible mechanism of action. Pestic Biochem Physiol 141:50-56

35. Williamson B, Tudzynski B, Tudzynski P, van Kan JAL (2007) Botrytis cinerea: the cause of grey mould disease. Mol Plant Pathol 8:561-580

36. Kwon M, Cochrane SA, Vederas JC, Ro D-K (2014) Molecular cloning and characterization of drimenol synthase from valerian plant (Valeriana officinalis). FEBS Lett 588:4597-4603

37. Fontes N, Gerós H, Delrot S (2011) Grape berry vacuole: a complex and heterogeneous membrane system specialized in the accumulation of solutes. Am J Enol Vitic 62:270-278

38. Brophy JJ, Forster PI, Goldsack RJ (1998) Essential oils of some Australian monimiaceae. Flavour Fragr J 13:273-276

39. Ledauphin J, Saint-Clair J-F, Lablanquie O, Guichard H, Founier N, Guichard E, Barillier D (2004) Identification of trace volatile compounds in freshly distilled calvados and cognac using preparative separations coupled with gas chromatography-mass spectrometry. J Agric Food Chem 52:5124-5134

40. Pannequin A, Tintaru A, Desjobert J-M, Costa J, Muselli A (2017) New advances in the volatile metabolites of Frullania tamarisci. Flavour Fragr J 32:409-418

41. Pino JA, Almora K, Marbot R (2003) Volatile components of papaya (Carica papaya L., Maradol variety) fruit. Flavour Fragr J 18:492-496

42. Cho IH, Choi H-K, Kim Y-S (2006) Difference in the volatile composition of pine-mushrooms (Tricholoma matsutake Sing.) according to their grades. J Agric Food Chem 54:4820-4825

43. Paolini J, Costa J, Bernardini A-F (2005) Analysis of the essential oil from aerial parts of Eupatorium cannabinum subsp. corsicum (L.) by gas chromatography with electron impact and chemical ionization mass spectrometry. J Chromatogr A 1076:170-178
44. Shimoda M, Wu Y, Osajima Y (1996) Aroma compounds from aqueous solution of haze (Rhus succedanea) honey determined by adsorptive column chromatography. J Agric Food Chem 44:3913-3918

45. Chung HY, Cadwallader KR (1993) Volatile components in Blue Crab (Callinectes sapidus) meat and processing by-product. J Food Sci 58:1203-1207

46. Brophy JJ, Goldsack RJ, O'Sullivan W (2004) Chemistry of the Australian gymnosperms Part VII. The leaf oils of the genus Actinostrobus. Biochem Syst Ecol 32:867-873

47. Chang LP, Sheng LS, Yang MZ, An DK (1989) Retention index of essential oil in temperature-programmed capillary column gas chromatography. Acta Pharm Sin 24:847-852

48. Castilho P, Liu K, Rodrigues AI, Feio S, Tomi F, Casanova J (2007) Composition and antimicrobial activity of the essential oil of Clinopodium ascendens (Jordan) Sampaio from Madeira. Flavour Fragr J 22:139-144

49. Verzera A, Trozzi A, Zappalá M, Condurso C, Cotroneo A (2005) Essential oil composition of Citrus meyerii Y. Tan. and Citrus medica L. cv. diamante and their lemon hybrids. J Agric Food Chem 53:4890-4894

50. Choi H-S, Lee Kim M-S, Sawamura M (2002) Constituents of the essential oil of cnidium officinale Makino, a Korean medicinal plant. Flavour Fragr J 17:49-53

51. Sing ASC, Smadja J, Brevard H, Maignial L, Chaintreau A, Marion J-P (1992) Volatile constituents of Faham (Jumellea fragrans (Thou.) Schltr.). J Agric Food Chem 40:642-646

52. Howard KL, Mike JH, Riesen R (2005) Validation of a solid-phase microextraction method for headspace analysis of wine aroma components. Am J Enol Vitic 56:37-45

53. Verzera A, Campisi S, Zappalà M, Bonaccorsi I (2001) SPMEGC-MS analysis of honey volatile components for the characterization of different floral origin. Am Lab 33:18-21

54. Chung TY, Eiserich JP, Shibamoto T (1993) Volatile compounds isolated from edible Korean Chamchwi (Aster scaber Thunb). J Agric Food Chem 41:1693-1697

55. Riu-Aumatell M, López-Tamames E, Buxaderas S (2005) Assessment of the volatile composition of juices of apricot, peach, and pear according to two pectolytic treatments. J Agric Food Chem 53:7837-7843

56. Njoroge SM, Koaze H, Karanja PN, Sawamura M (2005) Volatile constituents of Redblush grapefruit (Citrus paradisi) and Pummelo (Citrus grandis) peel essential oils from Kenya. J Agric Food Chem 53:9790-9794

57. Bousmaha L, Boti JB, Bekkara FA, Castola V, Casanova J (2006) Infraspecific chemical variability of the essential oil of Lavandula dentata L. from Algeria. Flavour Fragr J 21:368-372

58. Babushok VI, Linstrom PJ, Zenkevich IG (2011) Retention indices for frequently reported compounds of plant essential oils. J Phys Chem Ref Data 40:043101-1-043101-47

59. Boti JB, Koukoua G, N'Guessan TY, Muselli A, Bernardini A-F, Casanova J (2005) Composition of the leaf, stem bark and root bark oils of Isolona cooperi investigated by GC (retention index), GC-MS and ${ }^{13} \mathrm{C}-\mathrm{NMR}$ spectroscopy. Phytochem Anal 16:357-363

60. Pinto E, Pina-Vaz C, Salgueiro L, Gonçalves MJ, Costa-deOliveira S, Cavaleiro C, Palmeira A, Rodrigues A, Martinez-deOliveira J (2006) Antifungal activity of the essential oil of Thymus pulegioides on Candida, Aspergillus and dermatophyte species. J Med Microbiol 55:1367-1373

Publisher's Note Springer Nature remains neutral with regard to jurisdictional claims in published maps and institutional affiliations. 